\title{
Getting to Proficiency and Beyond: Kentucky Library Media Centers' Progress on State Standards and the Relationship of Library Media Program Variables to Student Achievement
}

\author{
Cynthia Houston, Ph.D. \\ Western Kentucky University \\ Program in Library Media Education \\ Cynthia.Houston@wku.edu
}

\section{Introduction}

As part of the nationwide professional standards movement in the 1990s, the American Association of School Libraries in partnership with the Association for Educational Communication and Technology published Information Power: Building Partnerships for Learning (1998). This document established national professional standards for school library media centers in schools across the country and created a new vision for 21 st school century media centers. To professional media specialists, Information Power standards represented a shift in their roles as "keepers of the books" to information technology specialists and instructional partners in a collaborative teaching and learning environment.

In Kentucky, Information Power was published at a critical time in the state's educational history. The Commonwealth was in the final stages of implementing the Kentucky Educational Reform Act (KERA), a comprehensive educational reform initiative designed to raise academic standards in Kentucky schools. The KERA curriculum incorporated critical thinking skills and integrated educational technology and information resources into the curriculum (Clark 2003). In 2001 the Kentucky Department of Education, with participation from school media specialists and administrators across the state, developed Beyond Proficiency: Achieving a Distinguished Library Media Program as a means to implement Information Power at the state level. The Beyond Proficiency document does not have the force of law in Kentucky, as do other KERA curriculum documents, but it does provide Kentucky media centers with specific performance expectations, guidelines for budget, staffing and program activities, 
and an evaluation rubric to gauge how media centers in the state "measure up" to the standards set by the school library media profession.

In order to get a better understanding of the status of school library media centers in Kentucky and to assess the progress of media centers on achieving the goals outlined in Beyond Proficiency, this survey of Kentucky library media specialists was developed and administered in 2006. This study follows a similar vein of research conducted in other states, which attempts to link research based standards for school library media centers and student achievement (Lance and Loertscher 2003). The primary purpose of the study is to provide a picture of the status of the Kentucky library media centers' level of achievement on state media center standards, and to identify significant characteristics of media center practices in high achieving primary and secondary schools. This study differs from previous state studies in that it uses a questionnaire based on a state approved standards document as opposed to the standardized survey instrument developed by Keith Curry Lance and the "Colorado team" (Lonsdale 2003). However, as Beyond Proficiency is based on research-based practice in library media education and national standards for library media centers, the results of the survey have the potential to provide important information linking library media centers and student achievement, which can be compared with results from other state wide studies.

\section{Purpose of the Study}

This study is designed to evaluate the status of school media centers in Kentucky in relation to the state standards published in Beyond Proficiency. The study will use the program evaluation rubric provided in the standards document to determine if media centers in Kentucky are in the "Apprentice" or "Proficient and Beyond" categories in each standard area on the evaluation rubric. In addition, the study will examine specific library variables, including budget, staffing, and flexible scheduling to see if they play a significant role in the ability of a media center to meet standards. Finally, this study will explore characteristics of media centers in high performing schools to determine if there are any significant practices that appear to contribute to student achievement. 


\section{National and State Standards for Library Media Centers}

As a response to A Nation at Risk, which revealed American schools' weaknesses in preparing children for the challenges of the next century, federal and state governments, along with professional education associations, worked cooperatively to develop national and state standards for nearly every facet of public education (National Commission on Excellence in Education 1983). Kentucky responded to this challenge when, as part of its comprehensive education reform initiative, the state department of education developed standards and expectations for the content areas, as well as for Kentucky's new and experienced teachers (Clements 1999). The Beyond Proficiency document, approved by the Kentucky Department of Education in 2001, was part of this movement. Beyond Proficiency, as a standards document for library media centers, is one of several state department of education approved standards documents for library media centers. Other states with standards include California, Texas, Massachusetts, Illinois, Kansas, Oregon, Minnesota, and Missouri (Misakian 2006). According to Beyond Proficiency, the standards for school library media centers support the Kentucky Department of Education "Getting to Proficiency" initiative, which sets a goal for Kentucky schools to reach specific performance standards by 2014.

Unlike the state curriculum documents, the recommendations for library media programs in terms of collection size, access to technology, budget and staffing levels in the Beyond Proficiency document have not been approved by the state legislature and therefore cannot be mandated. However, it can be presented to local and state school administrators as a set of professionally approved and state recommended guidelines for media centers.

There are thirteen standards in Beyond Proficiency, which are aligned with best practices for library media centers published in Information Power. The Beyond Proficiency document defines the scope of the library media education program in promoting reading and reading appreciation, technology integration, information literacy and collaboration for instruction, and delivery of media center services. The thirteen standards are listed below: 
1. The Library Media Center is accessible to all students and teachers

2. The Library Media Program promotes and supports student learning and achievement through its policies, programs and collections

3. The Library Media program supports collaborative planning with the staff for the enhancement of instruction and support of student achievement

4. The Library Media Program supports the principles of intellectual freedom, intellectual property rights, privacy rights, and ethical use of information. This is reflected in the program's policies, procedures, and practices as well as legal guidelines and professional ethics.

5. The Library Media Program provides access to a robust collection in a variety of formats in support of literacy, research and the curriculum. The collection also supports staff professional interests and innovative instruction.

6. The Library Media Program supports continual assessment and regular planning for development, implementation, and improvement of the LMC program.

7. The Library Media Program and its initiatives are promoted.

8. The Library Media Center is a technology resources center for the school.

9. The Library Media Center assumes-an active role in short-range planning as well as strategic planning in the school, district, and state

10. The Library Media Program is the focal point in the school for instructional resources, and the LMS partners with teachers in the delivery of a quality, integrated, and aligned curriculum.

11. The Library Media Center is administered by a media specialist who demonstrates professionalism by staying current with the profession and who adheres to the state and national standards for School Library Media specialists

12. The Library Media programs are a model of collaboration with other school-based program.

13. The Library Media Center is adequately funded and staff (2001, pp.20 - 25)

In order to assess the progress of library media centers in reaching "Proficiency and Beyond" in these standard areas, Beyond Proficiency includes a program evaluation rubric. The rubric breaks down each of the 13 standard areas into measurable attributes that characterize an "Apprentice," "Proficient," and "Distinguished" library media program in each of the standard areas. For example, in Standard 1 of the evaluation rubric, which addresses accessibility, a "Proficient" library media center program "is flexibly scheduled $50 \%$ of the time or more. The Library Media specialist and teachers collaborate for planning and designing instruction on a regular basis" (2001, p. 20). In the same standard area, an "Apprentice" program "is rigidly scheduled. Students come only at scheduled times during regular school hours. Teachers do not accompany the class. There is little or no collaboration between teachers and the LMS" (2001, p. 20). Because of the way in which each standard area is described using specific and observable 
attributes, it allows media specialists to identify the strengths and weaknesses of their programs. This rubric can be used as a launch pad for discussing with faculty and school administrators the role played by quality media centers in high achieving schools.

\section{Library Media Centers and Student Achievement Research: the State Studies}

Since the early 1990s over 16 states have participated in comprehensive surveys of media center practices. These studies collected descriptive data about the resources and activities in the media centers, evaluated the practices found in low versus high achieving schools, and also studied the relationships between media center practices and student achievement on state and national tests (American Library Association 2005; Lance 2002a; Lonsdale 2003; Scholastic Library Publishing 2006). Later studies grouped media center practices into learning and teaching, information access and delivery, and program administration to determine which characteristics in each of these areas had an impact on student learning (Lance 2002a). In every state study, significant relationships were found between specific library variables and student achievement measured by state and national tests. According to Lonsdale "existing research shows that school libraries can have a positive impact, whether measured in terms of reading scores, literacy, or learning more generally, on student achievement" (2003, p. 30). Furthermore, according to Lance, "Across states and grade levels, test scores correlated positively and statistically significantly to staff and collection size; library staff activities related to learning the teaching" (American Library Association 2005, para. 12) In his review of the state studies, Lance lists the following practices that have been found to be statistically significant in all of them:

- $\quad$ Professionally-trained and credentialed school library media specialists do make a difference that affects student performance on achievement tests

- In order for library media specialists to make this difference, the support of principals and teachers is essential

- Library media specialists cannot do their jobs effectively unless they have support staff who free them from routine tasks and enable them to participate in a variety of one-to-one and group meetings outside the library media center

- Library media specialists have a two-fold teaching role. They are teachers of students, facilitating the development of information 
literacy skills necessary for success in all content areas, and they are in-service trainers of teachers, keeping abreast of the latest information resources and technology

- $\quad$ Library media specialists also much embrace technology to be effective. They must ensure that school networks extend the availability of information resources beyond the walls of the LMC, throughout the building, and, in the best cases, into students' homes. (2002a, Common findings, para. 1)

In many of these studies results have also shown that media centers in schools serving low income communities often fall below guidelines for collection development resources, budget and staffing levels. However, the most significant aspect of these studies is the finding that when socio-economic levels are removed, small significant relationships between library media center practices and student achievement still exist, which demonstrates over and over again that school library media centers do contribute to student learning (Lance 2002b).

Kentucky was not a partner in any of the state studies of library media centers conducted over the past 15 years. However, one unpublished Kentucky study conducted by Allard and White (2000) does indicate that practices in Kentucky media centers also contribute to student achievement. Characteristics of library media centers in Kentucky's top scoring schools include:

- Student Technology Programs are more prevalent among the sample of top schools.

- Membership in professional associations is more evident in top schools.

- The top schools have a higher level of technology to offer students

- The Big Six is very prevalent at top secondary schools.

- Paid clerical assistance is more prevalent at the top schools.

- Top primary schools are more likely to have flexible scheduling.

- Evaluation of the LMS \& LMC is more specific and action oriented at top schools. (Allard and White 2002, pp. 2 - 4)

The Allard and White study indicates that school library media centers in Kentucky do play a role in student achievement. However, further research needs to be conducted to verify these results. In addition, it is important to determine if Kentucky school media 
centers are progressing in meeting standards set by Beyond Proficiency and what role media centers play in increasing student achievement. It is the purpose of this study to fill in the information gaps regarding school library media centers in Kentucky and provide evidence of media centers' contribution to student learning in the Commonwealth.

\section{Methodology}

\section{The Survey Instrument}

The survey instrument used in this study includes demographic information, school information, and the program evaluation rubric in the Beyond Proficiency document. The demographic information section includes questions about school location, the type of community the school serves, and grade levels the schools serves. The school information section includes questions about school size, the percentage of students served by the national school lunch program, and the type of assignment of the media specialist to the school (full- time or part-time, with out without assigned teaching duties). The Beyond Proficiency document program evaluation rubric was converted into a survey instrument by separating each sentence in the "Proficient" column of the rubric into individual statements answerable by selecting from "strongly disagree" to "strongly agree" or "yes" or "no." Because the evaluation rubric has been used throughout the state by administrators and media specialists to evaluate their media programs based on professional standards, the reliability and validity of this instrument to measure the 13 standard areas was assured. The survey pilot was tested in the fall of 2005 with media specialists in primary and secondary grade levels and revised according to their recommendations. The survey was first distributed in May 2006 to members of the Kentucky Library Media Specialists Listserv (KYLMS) via an email message that provided a link to the online survey document. A total of 35 media specialists responded to the survey. In September, an email message containing a link to the survey was sent to 592 library media specialists listed in the Kentucky Department of Education library media specialist electronic mailing list. Thirty-two of these emails were returned because the email address was no longer valid. After a follow up reminder email to the same list, the response rate to the survey was 56 percent, with 333 library media specialists responding to the survey. 


\section{Results}

Descriptive, non-parametric, correlation, and linear regression statistics in the Statistical Package for Social Sciences 4.0 program are used to analyze the data. Descriptive statistics provide an overall picture of the survey respondents and how they rate their media programs on Beyond Proficiency standards. Non parametric statistics are used to identify significant differences between practices of media centers in high achieving schools and other schools in the state. Correlation statistics are used to identify statistically significant relationships between Beyond Proficiency standards and whether or not the media center is staffed full time, has flexible scheduling or has a media specialist with assigned teaching duties. Linear regression statistics are used to determine which of the characteristics of media centers account for most of the variation between high scoring schools and other schools in the state.

Based on analysis of the demographic section of the survey, it appears that survey respondents are generally representative of schools in Kentucky in terms of their geographic distribution, socio economic status, and the grade levels served by the school (Kentucky Department of Education 2007). Thirty one percent of the respondents are from central Kentucky, the state's most populous region, while 23 percent are from eastern Kentucky, 19 percent are from western Kentucky, 14 percent are from northern Kentucky, and 11 percent are from south central Kentucky. A total of 41 percent of the schools are located in rural areas, 28 percent are in small towns, 17 percent are in urban areas, and 14 percent are in suburban areas. Of those media specialists responding to the survey, 64 percent report their school serves a student population where more than 50 percent qualify for free and reduced lunch. A majority of media specialists responding to the survey (58 percent) work in elementary school media centers, while 22 percent work in high school media centers, and 15 percent work in middle school media centers. About 4 percent of respondents work in schools they identified as "other."

A majority of survey respondents report that their schools fall into the middle range of scores on the Kentucky accountability measure referred to as the "CATS" test. A total of 
41 percent of the respondents state that their schools scored between 65 and 79 out of a possible 100 points on the combined CATS index, while 36 percent report their schools scored between 80 and 94 points. In the upper range of the CATS test, 11 percent of the schools report they scored between 95 and 100 points, while 6 percent of the schools report they scored more than 100 points in the assessment. In the lower range, 5.3 percent of the respondents report they scored between 50 and 64 points, while only 1 school reported a score below 50 points.

All but one of the media specialists responding to the survey indicated they held certification as school library media specialists. About 60 percent of the respondents report that their library media centers have a flexible schedule at least half the time. Only 44.8 percent of elementary school media centers have a flexible schedule at least 50 percent of the time, while all of the middle schools and 97 percent of the high schools have a flexible schedule at least 50 percent of the time. In regards to the assignment of the media specialist to the school, 84 percent of the media specialists report that they were assigned full time to one school while 42 percent reported that they had teaching duties in addition to their responsibilities as media specialists.

When reporting on minimum budget and staffing guidelines recommended by the Beyond Proficiency document 49 percent report their schools meet minimum media center budget allocations, 81 percent report their schools meet minimum guidelines for the number of books required in the media center collection, 32 percent report their schools meet minimum staffing guidelines for small schools (200 students or more) and 40 percent report their schools meet minimum guidelines for larger schools (500 students or more).

In order to develop a picture of how media centers rank their overall performance on the 13 Beyond Proficiency standards, the mean scores from responses to survey questions listed in each of the standard areas that used a Likert scale from 1 (strongly disagree) to 4 (strongly agree) were averaged, creating "standard mean score" for each standard. A "standard mean score" of three or higher is categorized as "Proficient or Beyond" for the purposes of this discussion, because responses were generally "agree" or "strongly agree" 
on questions in these standard areas. A "standard mean score" between 2 and 3 is categorized as "Apprentice" because respondents generally rated these standards as "strongly disagree," "disagree," or "agree". Those standards which were not measured using a Likert scale will be treated separately, but included in the overall report on how media specialists ranked their library media program on Beyond Proficiency standards. Table 1 shows the standards library media specialists rated as "Proficient or Beyond." In summary, school library media specialists indicate that their media centers are staffed by certified media specialists, their media centers serve as a focal point for instructional resources, and as a technology resource for the schools. Furthermore, their library media centers promote learning and achievement in literacy and information literacy, with access to a diverse collection of resources in a variety of formats. Finally, in these media centers, media specialists actively promote their programs and the principles of intellectual freedom are supported, modeled, and taught.

\section{Table 1: "Proficiency and Beyond" standards in library media centers}

\begin{tabular}{|c|c|c|}
\hline Standard & Description & $\begin{array}{c}\text { Standard } \\
\text { Mean Score }\end{array}$ \\
\hline 10 & $\begin{array}{l}\text { The LMP is the focal point in the school for instructional resources and } \\
\text { the LMS partners with teachers in the delivery of a quality, integrated } \\
\text { and aligned curriculum }\end{array}$ & 3.42 \\
\hline 7 & The LMP and its initiatives are promoted & 3.41 \\
\hline 2 & $\begin{array}{l}\text { The LMP promotes and supports student learning and achievement } \\
\text { through its policies, programs and collection }\end{array}$ & 3.39 \\
\hline 8 & The LMC is a technology resource center for the school & 3.14 \\
\hline 5 & $\begin{array}{l}\text { The LMP provides access to a robust collection in a variety of formats } \\
\text { in support of literacy, research and the curriculum. The collection also } \\
\text { supports staff professional interests and innovative instruction. }\end{array}$ & 3.02 \\
\hline 4 & $\begin{array}{l}\text { The LMP supports the principles of intellectual freedom, intellectual } \\
\text { property rights, and ethical use of information. This is reflected in the } \\
\text { program's policies procedures and practices as well as legal guidelines } \\
\text { and professional activities. }\end{array}$ & 3.02 \\
\hline 11 & $\begin{array}{l}\text { The LMC is administered by a media specialist who demonstrates } \\
\text { professionalism by staying current with the profession and who adheres } \\
\text { to the standards in the Evaluation Tool for library Media Specialists. }\end{array}$ & $\begin{array}{l}64 \% \text { belong to } \\
\text { KLA/KSMA } \\
75 \% \text { attend } \\
\text { professional } \\
\text { conferences } \\
69 \% \text { subscribe } \\
\text { to professional } \\
\text { journals }\end{array}$ \\
\hline
\end{tabular}


In contrast with the seven "Proficiency and Beyond" standard areas that media specialists indicated were program strengths, there were six standard areas media specialists generally rated at the "Apprentice" level. In these standard areas, standard mean scores fell between two and three, indicating media specialists sometimes selected "agree" but generally selected "disagree" or "strongly disagree" to questions in these standard areas. Table 2 shows the standards and standard mean scores. In summary, most of these standards relate to the following characteristics: below minimum funding and staffing levels, a lack of short and long term planning activities, a lack of collaborative programming and strategic planning activities, and below minimum accessibility to the media center.

Table 2: "Apprentice" standards in school library media centers

\begin{tabular}{|c|c|c|}
\hline Standard & Description & $\begin{array}{l}\text { Mean } \\
\text { score }\end{array}$ \\
\hline 13 & The LMC program is adequately funded and staffed & 2.68 \\
\hline 9 & $\begin{array}{l}\text { The LMC assumes an active role in short-range } \\
\text { planning as well as strategic planning in the school, } \\
\text { district, and state }\end{array}$ & 2.65 \\
\hline 3 & $\begin{array}{l}\text { The LMP supports collaborative planning with the } \\
\text { staff for the enhancement of instruction and support } \\
\text { of student achievement }\end{array}$ & 2.45 \\
\hline 1 & The LMC is accessible to all students and teachers & 2.42 \\
\hline 6 & $\begin{array}{l}\text { The LMP supports continual assessment and regular } \\
\text { planning for development of LMC programming }\end{array}$ & 2.03 \\
\hline 12 & $\begin{array}{l}\text { The LMC's programs are a model of collaboration } \\
\text { with other school based programs. }\end{array}$ & $\begin{array}{l}51 \% \text { Extended } \\
\text { School } \\
\text { Services, } 44 \% \\
\text { Family Service } \\
\text { Centers, } 21 \% \\
\text { Preschool }\end{array}$ \\
\hline
\end{tabular}

In order to determine how the practice of flexible scheduling and the presence of a full time media specialist with no assigned teaching duties affected performance on Beyond Proficiency standards, a Pearson r correlation analysis was performed. Table 3 provides a summary of the statically significant correlations from the analysis and shows that media centers staffed by full time media specialists, who have no additional teaching duties, and 
maintain a flexible schedule are more likely to meet many of the Beyond Proficiency standards. This is particularly true for elementary school media centers on a flexible schedule, staffed by a media specialist with no assigned teaching duties.

\section{Table 3: Pearson r Correlation Analysis of LMS Assignment and Beyond Proficiency Standards}

\begin{tabular}{|c|c|c|c|c|c|c|c|c|c|}
\hline & \multicolumn{3}{|c|}{ LMC has Flexible schedule } & \multicolumn{3}{|c|}{ LMS assigned full time } & \multicolumn{3}{|c|}{ LMS has no assigned teaching duties } \\
\hline & Elem & Middle & High & Elem & middle & High & Elem & Middle & High \\
\hline ST 1 & $\mathrm{r}=0.8 \mathrm{p} 0.000$ & $\begin{array}{l}\mathrm{r}=0.459 \\
\mathrm{p} 0.000\end{array}$ & $\begin{array}{l}\mathrm{r}=0.495 \\
\mathrm{p} 0.000\end{array}$ & & & & $\mathrm{r}=0.254 \mathrm{p} 0.000$ & & \\
\hline ST 2 & & $\begin{array}{l}\mathrm{r}=0.295 \\
\mathrm{p} 0.035\end{array}$ & $\begin{array}{l}\mathrm{r}=0.295 \\
\mathrm{p} 0.035\end{array}$ & & & & & & \\
\hline ST 3 & $\mathrm{r}=0.4 \mathrm{p} 0.000$ & & & & $\begin{array}{l}r=0.320 \\
p 0.022\end{array}$ & $\begin{array}{l}r=0.320 \\
p 0.022\end{array}$ & $\mathrm{r}=0.210 \mathrm{p} 0.004$ & & \\
\hline ST 4 & $\mathrm{r}=0.241 \mathrm{p} 0.001$ & & & & & & & & \\
\hline ST 5 & $\mathrm{r}=0.241 \mathrm{p} 0.001$ & $\begin{array}{l}\mathrm{r}=0.459 \\
\mathrm{p} 0.001\end{array}$ & $\begin{array}{l}\mathrm{r}=0.459 \\
\mathrm{p} 0.001\end{array}$ & & & & & & \\
\hline ST 6 & $\mathrm{r}=0.303 \mathrm{p} 0.003$ & & & & & & $\mathrm{r}=0.178 \mathrm{p} 0.013$ & & \\
\hline ST 7 & $=0.169 \mathrm{p} 0.019$ & $\begin{array}{l}\mathrm{r}=0.280 \\
\mathrm{p} 0.047\end{array}$ & $\begin{array}{l}\mathrm{r}=0.280 \\
\mathrm{p} 0.047\end{array}$ & & & & $\mathrm{r}=0.286 \mathrm{p} 0.000$ & $\mathrm{r}=0.299 \mathrm{p} 0.033$ & $\begin{array}{l}\mathrm{r}=0.299 \\
\mathrm{p} 0.033\end{array}$ \\
\hline ST 8 & $\mathrm{r}=0.309 \mathrm{p} 0.000$ & $\begin{array}{l}\mathrm{r}=0.314 \\
\mathrm{p} 0.025\end{array}$ & $\begin{array}{l}\mathrm{r}=0.314 \\
\mathrm{p} 0.025\end{array}$ & & $\begin{array}{l}r=0.345 \\
p 0.013\end{array}$ & $\begin{array}{l}r=0.345 \\
\mathrm{p} 0.013\end{array}$ & $\mathrm{r}=0.286 \mathrm{p} 0.000$ & & \\
\hline ST 9 & $\mathrm{r}=0.288 \mathrm{p} 0.000$ & & & & $\begin{array}{l}r=0.374 \\
p 0.007\end{array}$ & $\begin{array}{l}r=0.374 \\
p 0.007\end{array}$ & $\mathrm{r}=0.255 \mathrm{p} 0.000$ & & \\
\hline ST 10 & & $\begin{array}{l}\mathrm{r}=0.285 \\
\mathrm{p} 0.043\end{array}$ & $\begin{array}{l}\mathrm{r}=0.285 \\
\mathrm{p} 0.043\end{array}$ & & & & $\mathrm{r}=0.237 \mathrm{p} 0.001$ & & \\
\hline ST 13 & $\mathrm{r}=0.394 \mathrm{p} 0.000$ & & & & & & $\mathrm{r}=0.319 \mathrm{p} 0.000$ & & \\
\hline
\end{tabular}

In order to determine significant practices of media centers in high performing elementary, middle, and high schools, those schools who achieved an above average combined index scores of 80 or higher on the CATS accountability test were compared with schools with scores of 79 and below. A non-parametric Mann Whitney test was performed on the data. The analysis indicates that for all grade levels, high performing schools are less likely to have more than 50 percent of their students on free and reduced lunch, $(\mathrm{z}=-3.103, \mathrm{p}=0.002)$ more likely to meet minimum standards for the library media center budget, $(\mathrm{z}=-2.089, \mathrm{p}=0.037)$ and more likely to meet minimum standards for the size of the collection $(\mathrm{z}=-2.061, \mathrm{p}=0.039)$.

The non-parametric statistical analysis also indicates there are specific practices at the elementary level which are linked to high performing schools. At the elementary level, library media centers in high performing schools are likely to have achieved proficiency 
in Standard 2, which is related to supporting student learning ( $\mathrm{z}=-2.379 . \mathrm{p}=0.017)$. Specifically, library media programs in these schools appear to support a diversity of learning styles $(\mathrm{z}=-2.081, \mathrm{p}=0.037)$ and have access to a diverse collection $(\mathrm{z}=-2.566$, $\mathrm{p}=0.010)$.

A stepwise linear regression analysis was performed to determine which characteristics of media centers have the strongest association with student achievement measured by Kentucky's combined accountability index. The analysis was also performed to determine how much impact socio-economic status, measured by the percentage of students on free and reduced lunch in the school, had on student performance in comparison with the media center characteristics. Overall it appears that formal collaboration and promoting information literacy by using one of the process approaches has a greater impact on student test scores than socio-economic status. The adjusted $r$ squared for the percentage of students on free and reduced lunch was .350 and accounted for 7.5 percent of the variation in school index scores $(B=-.505, t=-3.263, p=0.002)$, while the adjusted $r$ squared for media centers in which media specialists engage in formal collaborative planning was 0.119 and accounted for 11.8 percent of the variation in test scores $(B=0.855, t=4.720, p=0.000)$, and the adjusted $r$ squared for media center programs that promote information literacy using one of the process approaches was 0.224 , accounting for 10.5 percent of the variation in scores $(B=0.492, t=4.281, p=0.000)$.

A stepwise linear regression analysis was also performed on data separated by elementary, middle, and high school to determine the significance of library media center characteristics at each of these levels. When schools are separated in this manner, it appears that specific media center characteristics have an impact on student achievement. In elementary schools, the adjusted r squared for achieving proficiency in Standard 2, which is related to promoting learning for all and having a diverse collection, was .251 and accounted for 12.4 percent of the variation in scores $(B=1.048, t=3.695, p=0.001)$. The adjusted $\mathrm{r}$ squared for formal collaboration was 0.315 and accounted for 7.4 percent of the variation in scores $(\mathrm{B}=0.623, \mathrm{t}=2.409, \mathrm{p}=0.020)$. The adjusted $\mathrm{r}$ squared in middle schools was 0.451 where information literacy instruction is provided by both the media 
specialist, and the classroom teacher $(\mathrm{B}=.313, \mathrm{t}=3.419, \mathrm{p}=0.005)$ while the adjusted $\mathrm{r}$ squared was 0.899 for the presence of a school media specialist with no assigned teaching duties accounted for 7.2 percent of the variation in scores $(\mathrm{B}=0.622, \mathrm{t}=2.863$, $\mathrm{p} 0 .=$ 0.019). At the high school level, it appears that having an inviting and well organized media center with a full time media specialist has the most significant impact on student achievement. The adjusted $r$ squared for having a media center organized effectively for the user was 0.562 and accounted for 24 percent of the variation in scores $(B=1.394$, $\mathrm{t}=4.373, \mathrm{p}=0.001$ ), while the adjusted $\mathrm{r}$ squared for having an inviting library media center was 0.675 and accounted for 11.3 percent of the variation in scores $(B=0.612$, $\mathrm{t}=2.531, \mathrm{p}=0.025$ ). The adjusted $\mathrm{r}$ squared for having a full time media specialist assigned to the school was 0.840 and accounted for 6.3 percent of the variation in scores $(\mathrm{B}=0.965$, $\mathrm{t}=2.711, \mathrm{p}=0.018$ ).

\section{Discussion, Conclusion, and Recommendations}

In responding to the initial question posed by this study--how do library media centers measure up to professional standards for library media centers listed in the Beyond Proficiency document?--the results of this survey provide a mixed answer. In six standard areas including standards two, four, five, seven, eight and eleven, library media centers in Kentucky do measure up. They are efficient and well organized, inviting, attractive technology and instructional resource centers, administered by professional media specialists who support the principles of intellectual freedom, promote technology integration, learning, achievement, literacy, and information literacy with a diverse collection of resources for a diverse community. The findings from this study indicate that particular characteristics of these standards, such as creating a well organized and inviting media center and housing a collection that supports diversity, has a positive impact on student achievement. In many ways these standards can be considered the most essential and important functions of school library media centers. Furthermore, the results of this survey indicate that media specialists, for the most part, "agree" or "strongly agree" that their media centers reach "Proficiency and Beyond" in these areas. 
In other standard areas media specialists indicate their media centers do not quite measure up, especially in standard areas one, three, six, nine, twelve and thirteen, which contain survey questions largely related to flexible scheduling, staffing and funding, accessibility, collaboration, and planning. In these areas it becomes clear that media centers fall short of reaching minimum funding and staffing guidelines and have difficulty maintaining a schedule or staffing levels to sustain long term strategic leadership and collaborative activities with teachers, administrators, other services agencies of the school, site based councils and advisory committees.

It appears that media specialists with assigned teaching duties and the lack of flexible scheduling in elementary libraries have the most difficulty with engaging in collaborative planning and instructional activities. This should be of concern to educators in Kentucky. The statistical analysis undertaken in this study indicates that media specialists who are engaged in formal collaborative planning, assigned full time to schools with no teaching duties are associated with higher achieving schools. Furthermore, these results concur with other state studies which also indicate that media specialists who are able to engage in collaborative planning for instruction positively impact student achievement (Lance \& Loertscher 2003). Comments made by media specialists on the Beyond Proficiency survey provide a picture of the situation many media specialists find themselves in related to the barriers they encounter when engaging in collaboration and leadership activities in the school:

I am excited at the thought of collaborating with classroom teachers. However, if the library isn't on a partial flex-time schedule you don't have any time to accomplish that. Library is still put in as a rotation of special areas in most elementary schools. It's really a shame, because I feel like I could do much more than be the keeper of the books.

Our biggest problem is scheduling. Collaboration does not occur because I see every class in the building 2 times a week including preschool. IF the scheduling were different then many things could be accomplished that aren't being done right now. Also, I don't have an aide therefore I don't even get books back on the shelf much less work on policies, procedures, and all the other things mentioned in the survey. 
Based on the results of the Beyond Proficiency survey, it appears that Kentucky school media centers provide their faculty and students with a strong library program, efficiently organized, rich in resources and potential to make a significant contribution to student achievement. It will be important in the near future to help Kentucky library media centers move to "Proficiency and Beyond" in all the standard areas, particularly those standards related to staffing levels, collaboration, and information literacy, which data indicate are associated with higher student achievement.

The conclusions from this study are limited to the state of Kentucky and may be biased due to the characteristics of the media specialists who responded to the survey. However, this study does indicate that barriers still exist in creating high quality library media centers in Kentucky--which are primarily issues of scheduling, budget, and staffing. As all of these decisions are under the purview of school administrators and site base decision making council members. It is important that media specialists and their supporters make the case for school libraries at the local, state and national levels. According to Keith Curry Lance, "the era of standards based testing has also been the era of site based management, leaving the fate of most school libraries in the hands of principals and other building level decision makers rather than a matter of state or district policy" (American Library Association 2005, SMLR Questions and Comments D). Additionally, further research in areas showing the relationships between school libraries and achievement in Kentucky, along with more advocacy for quality school libraries, will be required to move Kentucky school media centers to Beyond Proficiency in these important standard areas.

\section{References}

Allard, S. and White, J., (2000). Comparisons of CATS scores and library media reports. University of Kentucky. http://www.pld.fayette.k12.ky.us/lms/catsscores.doc (accessed October 30, 2006).

American Association of School Librarians and the Association for Educational Communications and Technology. (1998). Information power: Building partnerships for learning. Chicago: American Library Association.

American Library Association. (2007). The state of America's libraries 2007. 
http://www.ala.org/ala/pressreleases2007/march2007/stateoflibraries.htm. (accessed June 20, 2007)

American Library Association. (2005). Enough already? Blazing new trails for school library research? An interview with Keith Curry Lance American Library Association, July 24, 2006. http://www.ala.org/ala/aasl/aaslpubsandjournals/slmrb/editorschoiceb/lance/interv iewlance.cfm (accessed August 9, 2007).

Clark, M. (2003). Education reform, redistribution, and student achievement: Evidence from the Kentucky Education Reform Act. Princeton, NJ: Mathematica Policy Research. http://www.princeton.edu/ maclark/kera.pdf (accessed August 7, 2007).

Clements, S. (1999). Kentucky teachers: Charting a course for KERA's second decade. Frankfort, KY: Kentucky Long-Term Policy Research Center. http://www.kltprc.net/books/kysteachers/entry.htm (accessed August 7, 2007).

Kentucky Department of Education. (2001). Beyond proficiency: Achieving a distinguished library media program. Frankfort, KY: Kentucky Department of Education. http://www.kde.state.ky.us/NR/rdonlyres/953D6B19225D-4B43-95C0-951B17A43445/0/beyondproficiency.pdf (accessed August 7, 2007).

Kentucky Department of Education. (2007). Kentucky education facts. http://www.kyschools.org/KDE/HomePageRepository/News+Room/Kent ucky+Education+Facts.htm (accessed August 7, 2007).

Lance, K. (2002a). Impact of school library media programs on student achievement. Teacher Librarian 29(3): 29.

Lance, K. (2002b). How school librarians leave no-child behind: The impact of school library media programs on academic achievement of U.S. public school students. School Libraries in Canada 22(2): 3 - 6.

Lance, K. and Loertscher, D., (2003). Powering achievement: school library media centers make a difference. 2nd edition. Salt Lake City, UT: Hi Willow Research

Lonsdale, M. (2003). Impact of school libraries on student achievement: A review of the research. Camberwell, Victoria: Australian Council for Educational Research. http://www.asla.org.au/research/research.pdf (accessed August 7, 2007).

Michie, J. S. and Chaney, B.W., (2005). Improving literacy through school libraries evaluation. Washington, D.C: United States Department of Education 
Office of Planning, Evaluation, and Policy Development, Policy and Program Studies Services.

http://eric.ed.gov/ERICDocs/data/ericdocs2sq1/content_storage_01/0000019b/80/ 1b/be/06.pdf (accessed August 7, 2007).

Michie, J. S. and Holton, B., (2005). America's public school libraries 1953 - 2000. Washington, D.C.: National Center for Education Statistics. http://libraryworkforce.org/tiki-download_file.php?fileId=36 (accessed August 7, 2007).

Michie, J. S. and Holton, B., (2005). Fifty years of supporting children's learning: A history of public school libraries and federal legislation from 1953 to 2000. Washington, D.C.: National Center for Education Statistics. http://nces.ed.gov/pubs2005/2005311.pdf (accessed August 7, 2007).

Misakian, J.E. (2006). The synergistic attribute of library media center standards. Library Media Connection. 24(4): 22 - 24.

National Commission for Excellence in Education. (1983). A Nation at Risk: The Imperative for Educational Reform. Washington, D.C.: National Commission for Excellence in Education. http://www.ed.gov/pubs/NatAtRisk/title.html (accessed August 7, 2007).

National Center for Educational Statistics. (2005). School library media centers: selected results from the educational longitudinal study of 2002. Washington: DC National Center for Educational Statistics. http://nces.ed.gov/pubs2005/2005302.pdf (accessed August 7, 2007).

Neuman, D. (2003). Research in school library media for the next decade: polishing the diamond. Library Trends. 51(4): 503 - 524.

Scholastic Library Publishing (2006). School libraries work 2006 edition. New York: Scholastic. www.scholastic.com/librarians/printables/downloads/slw_2006.pdf (accessed August 7, 2007). 